J-ABDIPAMAS (Jurnal Pengabdian Kepada Masyarakat)

Vol. $2 \bullet$ No. $2 \bullet 2018$

ISSN : 2581-1320 (Print) ISSN : 2581-2572 (Online)

Homepage: http://ejurnal.ikippgribojonegoro.ac.id/index.php/J-ABDIPAMAS

\title{
PEMBERDAYAAN GURU DALAM MENGEMBANGKAN METODE PEMBELAJARAN AKTIF BERKARAKTER ISLAM RAHMATAN LIL'ALAMIN
}

\author{
Imam Mawardi ${ }^{1}$, Akhmad Baihaqi², Rochim Widaryanto ${ }^{3}$
}

1Universitas Muhammadiyah Magelang. Email: mawardirazal@ummgl.ac.id 2Universitas Muhammadiyah Magelang. Email: akhmadbaihaqi@ummgl.ac.id

3Universitas Muhammadiyah Magelang. Email: rochimxwidaryanto@gmail.com

\begin{abstract}
This article is the result of the community partnership program (PKM) which aims to improve teacher competency in the development of active learning methods characterized by Islam rahmatan lil'alamin at SD Muhammadiyah Pujotomo and MI Muhammadiyah Danurejo of MertoyudanMagelang. These two institutions have problems, one of which is related to competence in managing learning; the teachers tend to be conventional in applying learning methods and cannot yet relate learning to Islamic approaches. Even though the content in Islamic education institutions should show the characteristics of Islamic nuances of learning. The solution to overcome this problem is to equip teachers with the active learning method with the character of Islam rahmatan lil 'alamin; as a form of actualization of the development of teacher's pedagogical abilities. The method in this PKM uses the Participatory Rural Apraissal (PRA) model, by involving partners in determining the problem solving faced. The results obtained indicate an increase in the ability of teachers in designing and developing active learning methods characterized by the character of Islam rahmatan lil'alamin, and is an innovation step in the development of the 2013 curriculum which emphasizes the strengthening of character education.
\end{abstract}

Keywords: active learning method, Islam rahmatan lil'alamin, empowering teachers

\begin{abstract}
ABSTRAK
Artikel ini merupakan hasil dari program kemitraan masyarakat (PKM) yang bertujuan untuk meningkatkan kompetensi guru dalam pengembangan metode pembelajaran aktif berkarakter Islam rahmatan lil'alamin di SD Muhammadiyah Pujotomo dan MI Muhammadiyah Danurejo, Kecamatan Mertoyudan Kabupaten Magelang. Dua lembaga ini mempunyai masalah, salah satunya adalah berkaitan dengan kompetensi dalam mengelola pembelajaan; para guru cenderung konvensional dalam menerapkan metode pembelajaran dan belum bisa mengaitkan pembelajaran dengan pendekatan Islami. Padahal seharusnya muatan di lembaga pendidikan Islam harus menunjukkan karakteristik pembelajaran yang bernuansa islami. Solusi untuk mengatasi masalah tersebut adalah membekali para guru dengan metode pembelajaran aktif berkarakter Islam rahmatan lil 'alamin; sebagai bentuk aktualisasi pengembangan kemampuan pedagogik guru. Metode dalam PKM ini mengunakan model Participatory Rural Apraissal (PRA), dengan melibatkan mitra dalam penentuan pemecahan masalah yang dihadapi. Hasil yang diperoleh menunjukkan adanya peningkatan kemampuan guru dalam merancang dan mengembangkan metode pembelajaran aktif berkarakter Islam rahmatan lil'alamin, dan merupakan suatu langkah inovasi pengembangan kurikulum 2013 yang mengedepankan penguatan pendidikan karakter.
\end{abstract}

Kata Kunci: metode pembelajaran aktif, Islam rahmatan lil'alamin, pemberdayaan guru 


\section{PENDAHULUAN}

Problematika pendidikan yang terjadi di masyarakat sekolah tidak bisa dilepaskan dari kualitas SDM guru yang kurang mempunyai kompetensi dalam mensikapi berbagai permasalahan yang muncul, baik dalam manajemen kurikulum pembelajaran, maupun penguatan karakter peserta didik. Kebutuhan peningkatan kompetensi guru merupakan salah satu syarat untuk menjamin mutu pendidikan secara komprehensif. Hal ini sebagaimana dijelaskan dalam Undang-Undang Guru dan Dosen Nomor 14 Tahun 2005 Pasal 8 disebutkan bahwa:

"Guru wajib memiliki kualifikasi akademik, kompetensi, sertifikat pendidik, sehat jasmani dan rohani, serta memiliki kemampuan untuk mewujudkan tujuan pendidikan nasional. Kompetensi guru sebagaimana dimaksud dalam undang-undang tersebut meliputi kompetensi pedagogis, kompetensi kepribadian, kompetensi sosial, dan kompetensi profesional yang diperoleh melalui pendidikan profesi."

Secara ideal masing-masing kompetensi yang harus dimiliki guru menurut Prastowo (2011) adalah harus mampu mengembangkan kurikulum yang terkait dengan bidang pengembangan yang diampu, menyelenggarakan kegiatan pengembangan yang mendidik, mengembangkan materi pembelajaran secara kreatif dan memanfaatkan teknologi informasi dan komunikasi untuk berkomunikasi dan mengembangkan diri. Apalagi menghadapi tantangan globalisasi, di mana peran guru dalam menanamkan nilai-nilai melalui pembelajaran menjadi kebutuhan mendesak yang tidak bisa diabaikan begitu saja.

Dengan demikian, atas tuntutan tersebut seorang guru mampu mendesain dan mempraktekkan metode pembelajaran aktif yang berkarakter Islam rahmatan lil'alamin; yaitu sebuah metode pembelajaran aktif, inovatif, kreatif, efektif dan menyenangkan (PAIKEM), sekaligus menumbuhkembangkan budaya Islam Indonesia yang toleran, humanis, dan demokratis (Direktorat Jenderal Pendidikan Islam, 2015).

Lokasi mitra dalam PKM ini adalah SD Muhammadiyah Pujotomo yang terletak di Desa Pandansari Kecamatan Mertoyudan dan MI Muhammadiyah Danurejo Kecamatan Mertoyudan, keduanya berada dalam wilayah Kabupaten Magelang Propinsi Jawa Tengah. Jarak UMMagelang (Kampus 2) ke lokasi SD Muhammadiyah Pujotomo adalah 1 KM, MI Muhammadiyah Danurejo Kecamatan Mertoyudan 3 KM.

Usaha-usaha pengembangan pendidikan di kedua mitra sekolah ini, terus diupayakan oleh pengelolah dan yayasan untuk memenuhi standar pendidikan, misalnya salah satunya melalui akreditasi sekolah. Meskipun berbagai upaya dilakukan tetapi persoalan tak bisa lepas begitu saja. Beberapa persoalan yang diperoleh dari kedua sekolah ini mengerucut pada kesimpulan yang sama, diantaranya: (a) Sekolah dilihat dari lingkungan, sarpras dan ketersediaan SDM guru cukup memadahi, meskipun anggaran untuk pengembangan pendidikan 
sangat kurang; (b) Sekolah kurang diminati masyarakat, hal ini terindikasi dari jumlah siswa yang minim dari daya tampung yang diharapkan; (c) Siswa nampak tidak bersemangat dan kurang motivasi dalam menerima pembelajaran dari gurunya, padahal metode yang digunakan sudah bervariasi meskipun masih nampak konvensional dan kaku; (d) Guru dalam mengajar belum bisa mengkonstekstualisasikan materi dengan pendekatan islami, padahal guru-guru tersebut mengajar di lembaga pendidikan Islam; (e) Out put siswa dalam hal pembentukan karakter keagamaan dan sosial belum menunjukkan sikap yang diharapkan, padahal seharusnya out put pendidikan Islam harus lebih baik daripada pendidikan umum.

Mengacu pada analisis situasi, ditemukan masalah prioritas mitra PKM, solusi dan target luaran, sebagaimana tabel 1.

Tabel 1: Solusi dan Target Luaran PKM

\begin{tabular}{|c|c|c|c|}
\hline No & Jenis Permasalahan & Solusi & Target Luaran \\
\hline 1 & $\begin{array}{l}\text { Dari segi sosial, belum ada } \\
\text { sosialisasi tentang } \\
\text { peningkatan kompetensi } \\
\text { guru dalam pengembangan } \\
\text { metode pembelajaran aktif } \\
\text { berkarakter Islam } \\
\text { rahmatan lil'alamin. }\end{array}$ & \multirow{2}{*}{$\begin{array}{l}\text { Mengadakan } \\
\text { pelatihan metode } \\
\text { pembelajaran aktif } \\
\text { secara } \\
\text { komprehensif, } \\
\text { meliputi } \\
\text { pengembangan } \\
\text { desain } \\
\text { pembelajaran, } \\
\text { simulasi metode, } \\
\text { dan praktik micro } \\
\text { teaching. }\end{array}$} & \multirow{2}{*}{$\begin{array}{l}\text { a. Meningkatnya Kompetensi } \\
\text { guru dalam dalam } \\
\text { menggunakan metode } \\
\text { pembelajaran } \\
\text { b. Meningkatnya pemahaman } \\
\text { guru tentang pembelajaran } \\
\text { Islam Karakter Rohmatan } \\
\text { Lilalamin } \\
\text { c. Terciptanya guru yang kreatif } \\
\text { d. Terwujudnya guru yang ber } \\
\text { inovasi dalam pendidikan }\end{array}$} \\
\hline 2 & $\begin{array}{l}\text { Dari segi budaya, proses } \\
\text { pembelajaran yang } \\
\text { dilakukan guru di kedua } \\
\text { mitra sekolah masih } \\
\text { bersifat konvensional, dan } \\
\text { kurang ada kemauan } \\
\text { untuk berinovasi dalam } \\
\text { pembelajaran. }\end{array}$ & & \\
\hline 3. & $\begin{array}{l}\text { Dari segi ekonomi, } \\
\text { terbatasnya sumber dana } \\
\text { yang ada di kedua mitra } \\
\text { untuk mengadakan } \\
\text { kegiatan peningkatan } \\
\text { kompetensi guru. }\end{array}$ & \multirow[t]{2}{*}{$\begin{array}{l}\text { Pendampingan } \\
\text { Guru di sekolah } \\
\text { untuk dapat } \\
\text { mengembangkan } \\
\text { pembelajaran } \\
\text { secara mandiri. }\end{array}$} & $\begin{array}{l}\text { a. Produk RPP yang berkarakter } \\
\text { Islam Rahmatan Lil 'alamin } \\
\text { b. Rumusan penggunaan } \\
\text { metodologi pembelajaran } \\
\text { yang sesuai dengan } \\
\text { karakteristik materi dan }\end{array}$ \\
\hline 4. & $\begin{array}{l}\text { Dari segi spirit keagamaan, } \\
\text { proses internalisasi nilai } \\
\text { karakter yang dilakukan } \\
\text { guru kepada siswa belum } \\
\text { menyentuh nilai karakter } \\
\text { rahmatan lil'alamin. }\end{array}$ & & $\begin{array}{l}\text { karakteritik peserta didik } \\
\text { c. Terpenuhinya media } \\
\text { pembelajaran yang sesuai } \\
\text { dengan karakter Islam } \\
\text { Rahmatan lil alamin } \\
\text { d. Guru mampu mengadakan } \\
\text { evaluasi yang berkarakter } \\
\text { Islam Rahmatan lil alamin }\end{array}$ \\
\hline
\end{tabular}

Dari permasalahan tersebut di atas, akhirnya dapat dikerucutkan ke dalam permasalahan khusus, yaitu persoalan yang berhubungan dengan kompetensi SDM guru yang kurang mampu meramu metode pembelajaran aktif dan belum bisa mengaitkan materi pelajaran dengan nilai-nilai kehidupan peserta didik. 


\section{METODE PELAKSANAAN}

Dengan memperhatikan permasalahan yang ada, pendekatan yang digunakan untuk PKM adalah metode pemberdayaan masyarakat partisipatif atau Participatory Rural Apraissal (PRA), yang dilaksanakan dalam bentuk wokshop pelatihan dan pendampingan dalam pengembangan metode dan perangkat pembelajaran lainnya. Secara lebih rinci metode kegiatan dapat dijelaskan dengan mengikuti tahap sebagaimana dalam tabel 2 .

Tabel 2 Metode Pelaksanaan Kegiatan

\begin{tabular}{|c|c|c|c|}
\hline Tahap & Rencana Kegiatan & Metode & Hasil \\
\hline 1 & $\begin{array}{l}\text { Persiapan, analisis } \\
\text { masalah/kebutuhan dan } \\
\text { potensi pemberdayaan }\end{array}$ & $\begin{array}{l}\text { - Observasi } \\
\text { - Wawancara }\end{array}$ & $\begin{array}{l}\text { Data masalah yang } \\
\text { teridentifikasi }\end{array}$ \\
\hline 2 & Penetapan prioritas & $\begin{array}{l}\text { FGD dengan } \\
\text { mitra }\end{array}$ & Prioritas masalah ditentukan \\
\hline 3 & $\begin{array}{l}\text { Penentuan solusi } \\
\text { pemecahan masalah }\end{array}$ & $\begin{array}{l}\text { FGD dengan } \\
\text { mitra }\end{array}$ & $\begin{array}{l}\text { Penentuan: } \\
\text { - Alternatif pemecahan } \\
\text { masalah } \\
\text { - Jadwal kegiatan } \\
\text { - Tempat pelaksanaan } \\
\text { - Peserta }\end{array}$ \\
\hline 4 & $\begin{array}{l}\text { Perencanaan dan } \\
\text { pengorganisasian } \\
\text { kegiatan }\end{array}$ & $\begin{array}{l}\text { Analisis } \\
\text { pemetaan }\end{array}$ & $\begin{array}{l}\text { - Desain kurikulum workshop } \\
\text { - Penyiapan modul } \\
\text { pembelajaran berkarakter } \\
\text { Islam rahmatan lil'alamin } \\
\text { - Pembagian tugas sesuai } \\
\text { dengan kepakaran yang } \\
\text { dimiliki }\end{array}$ \\
\hline 5 & $\begin{array}{l}\text { Pelaksanaan } \\
\text { Pendampingan Metode } \\
\text { Pembelajaran } \\
\text { Berkarakter Islam } \\
\text { Rahmatan Lil'alamin }\end{array}$ & $\begin{array}{l}\text { - Workshop } \\
\text { - Pelatihan } \\
\text { - Pendampingan }\end{array}$ & $\begin{array}{l}\text { - Penguatan karakter Islam } \\
\text { rahmatan lil'alamin } \\
\text { - Pengembangan metode } \\
\text { pembelajaran aktif } \\
\text { - Pengembangan media } \\
\text { pembelajaran berbasis } \\
\text { powerpoint } \\
\text { - Perencanaan pembelajaran }\end{array}$ \\
\hline 6 & $\begin{array}{l}\text { Penerapan terbimbing } \\
\text { metode pembelajaran } \\
\text { berkarakter islam } \\
\text { rahmatan lil'alamin }\end{array}$ & $\begin{array}{l}\text { - } \text { Praktik micro } \\
\text { teaching } \\
\text { - Praktik real } \\
\text { teaching }\end{array}$ & $\begin{array}{l}\text { Pembelajaran aktif berkarakter } \\
\text { rahmatan lil'alamin }\end{array}$ \\
\hline 8 & $\begin{array}{l}\text { Evaluasi dan rencana } \\
\text { tindak lanjut }\end{array}$ & FGD & $\begin{array}{l}\text { Kesinambungan program } \\
\text { pelatihan dan implementasi } \\
\text { dalam pembelajaran }\end{array}$ \\
\hline
\end{tabular}

Pelaksanaan PKM ini target dan luarannya terhadap mitra adalah meningkatnya kompetensi guru dalam mengembangkan pembelajaran berkarakter rahmatan lil'alamin melalui penerapan metode pembelajaran aktif, pengembangan media power point, dan penyusunan rencana pembelajaran; sehingga guru sebagai mitra PKM mampu memecahkan permasalahan dalam 
mengelola pembelajaran dan meningkatkan kualitas prestasi peserta didik. Adapun target dari PKM ini adalah guru-guru pada pendidikan dasar amal usaha Muhammadiyah se-Kecamatan Mertoyudan, Kabupaten Magelang, yaitu di SD Muhammadiyah Pujotomo dan MI Muhammadiyah Donorojo

\section{HASIL DAN PEMBAHASAN}

Hasil dari PKM dapar diklasifikasi dari beberapa kegiatan yang terintegrasi dalam bentuk pelatihan/workshop dan pendampingan bagi guru, yaitu:

\section{Penguatan Karakter Islam Rahmatan Lil'alamin}

Kegiatan penguatan karakter Islam rahmatan lil'alamin bertujuan memberikan wawasan mitra tentang konsep Islam rahmatan lil 'alamin dan aktualisasinya dalam pembelajaran. Materi yang disampaikan dalam workshop ini adalah: pertama, pemahaman tentang Iman, Islam, dan Ihsan dengan makna, cakupan, serta implementasinya sebagai dasar dalam menerapkan karakter Islam rahmatan lil'alamin. Kedua, pemahaman tentang ajaran Islam yang mengajarkan tentang toleransi, demokrasi dan pluralitas dalam kehidupan bermasyarakat, sebagai pemahaman Islam yang rahmatan lil 'alamin yaitu rahmat bagi seluruh alam semesta.

Harapan dari pelatihan ini adalah agar guru dapat mengaplikasikan konsep Islam rahmatan lil 'alamin dalam kegiatan pembelajaran. Guru bisa mengajarkan segala materi dengan menyelipkan karakter Islam rahmatan lil 'alamin, yaitu pembelajaran yang menekankan kasih sayang dan tidak diskriminatif, menumbuhkan nilai kemanusiaan dan toleransi, serta menghargai tentang perbedaan baik dari bentuk fisik, suku, ras, golongan ataupun yang lainnya.

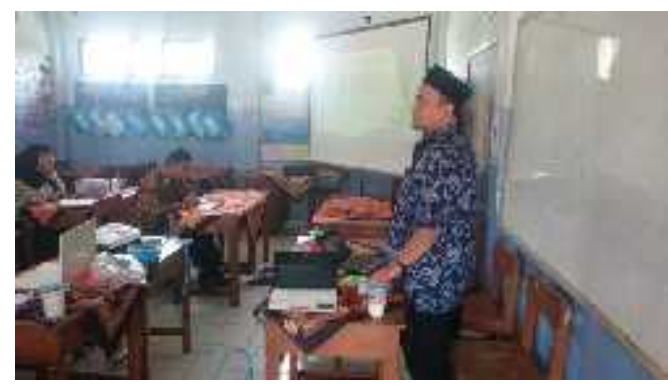

Gambar 1. Workshop Penguatan Konsep Islam Rahmatan Lil ‘Alamin

\section{Pengembangan Media Power Point dalam Pembelajaran}

Tujuan dari kegiatan ini adalah supaya mitra (guru) bisa mengoptimalkan media pembelajaran melalui pengembangan media power point. Sehingga diharapkan melalui pemdampingan ini memudahkan bagi guru dalam menyamaikan pesan-pesan pembelajaran kepada peserta didik, demikian juga peserta didik dengan adanya media ini lebih terbantu dalam memahami materi pembelajaran yang disampaikan guru.

Dalam kegiatan ini para guru praktik secara langsung, dengan dua titik fokus yang diutamakan. Fokus yang pertama adalah bagaimana cara membuat file 
presentasi (media power point) dengan menarik. Sedangkan fokus yang kedua adalah pendampingan tentang hyperlink dalam power point. Demikian juga disampaikan dalam pendampingan, tentang beberapa langkah supaya file presentasi (power point) lebih menarik, diantaranya adalah pemilihan warna, penggunaan fitur desain yang ada pada power point (shape, smart art, chart, dll).

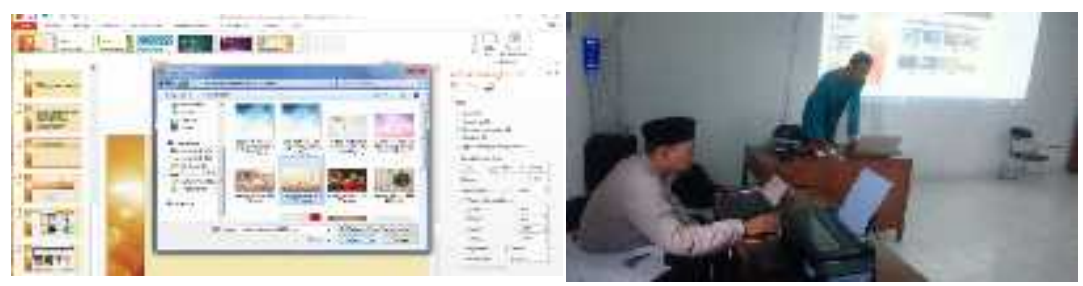

Gambar 2. Contoh langkah membuat file presentasi menarik dan pendampingan hyperlink

\section{Pengembangan Metode Pembelajaran Aktif}

Tujuan kegiatan ini adalah supaya mitra menjadi sosok pendidik yang kreatif dalam mengembangkan metode pembelajaran aktif dan mampu menginternalisaikan nilai-nilai Islam rahmatan lil'alamin dengan baik. Metode yang dilaksanakan dalam pendampingan ini adalah metode ceramah, tanya jawab, diskusi, demontrasi, dan unjuk kerja. Tim pengabdian membagi pendampingan ini ke dalam beberapa sessi. Sessi yang pertama adalah penyampaian materi tentang macam-macam metode pembelajaran. Diawali dengan mengidentifikasi macammacam metode yang sudah sering dilakukan oleh mitra pada waktu kegiatan pembelajaran. Selanjutnya Tim memberikan materi macam-macam metode dengan menggunakan pijakan metode pembelajaran Active Learning.

Untuk lebih efisien dan membangun rasa kerjasama maka mitra dibagi menjadi empat kelompok. Masing-masing kelompok mendiskusikan modul metode pembelajaran yang dibagikan oleh Tim pengabdian. Dalam modul tersebut terdapat beberapa macam contoh media pembelajaran yang harus dikuasai oleh mitra. Diantaranya ada metode market place activity, mind mapping, think pair and share, poster comment, dll.

Setelah penyampaian materi selesai, sessi selanjutnya adalah diskusi. Diskusi dilakukan untuk saling berkomunikasi antar anggota kelompok berbagi ide-ide kreatif. Dengan menggunakan metode poster comment masing-masing kelompok diberikan sebuah gambar kemudian untuk memberikan komentar terbaik di bawah gambar tersebut. Setelah selesai gambar tersebut dipresentasikan dan ditempelkan di dinding.

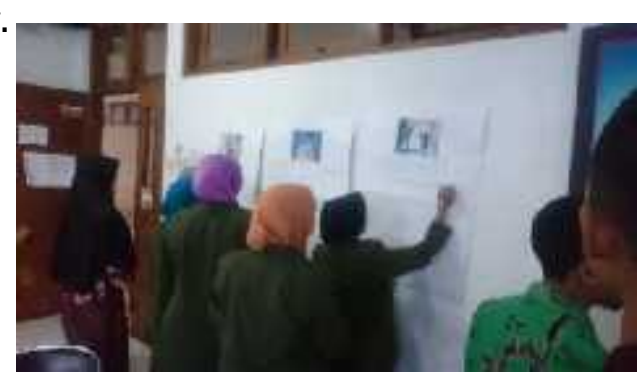

Gambar 3. Pendampingan Pengembangan Metode Pembelajaran 


\section{Penyusunan Perencanaan Pembelajaran}

Perangkat pembelajaran adalah seperangkat dokumen-dokumen yang digunakan seorang guru sebagai patokan dalam pembelajarannya. Perangkat pembelajaran bisa dikatakan sebagai alat memasak bagi seorang guru. Maka ia harus mempersiapkan alat memasaknya sebelum ia mengajar. Diantara perangkat pembelajaran seorang guru adalah adanya RPP, Silabus, Program semester, program tahunan, dafta nilai, dan lain sebagainya.

Pada pendampingan ini, Tim memfokuskan pendampingan pada penyusunan perangkat pembelajaran yang berupa Rencana Pelaksanaan Pembelajaran (RPP) sesuai kurikulum 2013 revisi 2017. Namun sebelum praktik menyusun RPP, Tim Pengabdian melakukan refresing tentang materi kurikulum 2013 dan revisi tahun 2017. Hasil perbaikan berkenaan dengan (1) Koherensi KI-KD dan penyelarasan dokumen; (2) Penataan kompetensi Sikap Spiritual dan Sikap Sosial pada semua mata pelajaran; (3) Penataan kompetensi yang tidak dibatasi oleh pemenggalan taksonomi proses berpikir (berpikir tingkat tinggi sejak SD); (4) Pemberian ruang kreatif kepada guru dalam mengimplementasikan kurikulum. (BPP, 2017).

Perbaikan atau revisi Kurikulum 2013 tahun 2017, juga mengintegrasikan (1) Penguatan Pendidikan Karakter (PPK) di dalam pembelajaran. Karakter yang diperkuat terutama lima karakter, yaitu: religius, nasionalis, mandiri, gotong royong, dan integritas; (2) Literasi, Pengertian Literasi dalam konteks Gerakan Literasi Sekolah (GLS) adalah kemampuan mengakses, memahami, dan menggunakan sesuatu secara cerdas melalui berbagai aktivitas antara lain membaca, melihat, menyimak, menulis, dan/atau berbicara; (3) Keterampilan abad 21 atau diistilahkan dengan 4C (Creative, Critical thinking, Communicative, dan Collaborative). $4 \mathrm{C}$ adalah jenis softskill yang pada implementasi keseharian, jauh lebih bermanfaat ketimbang sekadar pengusaan hardskill; (4) HOTS (Higher Order Thinking Skill) adalah kemampuan berpikir kritis, logis, reflektif, metakognitif, dan berpikir kreatif yang merupakan kemampuan berpikir tingkat tinggi. (BPP, 2017)

Setelah refressing terhdap perubahan kurikulum tahun 2017 dilanjutkan dengan penyusunan RPP dengan menggunakan prinsip learning by doing. Tim pengabdian dengan terlebih dahulu memberikan panduan format langkah-langkah menyusun RPP. Dalam menyusun RPP yang perlu dipersiapkan guru adalah kurikulum yang memuat tentang Kompetensi inti, standar kompetensi, materi, dan alokasi waktu.

Kemudian dilanjutkan dengan penjelasan komponen yang ada pada Rencana Pelakasanaan Pembelajaran (RPP). Komponen yang ada pada RPP diantaranya adalah Identitas, Kompetensi inti, Kompetensi dasar dan Indikator, Tujuan Pembelajaran, Materi Pembelajaran, Metode Pembelajaran, Media Pembelajaran, Sumber belajar, Langkah-langkah pembelajaran, penilaian hasil belajar, dan Lampiran. Dari kesemua komponen yang ada, semuanya dijelaskan satu persatu tentang langkah- langkah penyusunan, konten, serta beberapa revisi yang sudah berlaku. 
Setelah penyampaian materi selesai, kegiatan selanjutnya adalah kegiatan tanya jawab. Para peserta workshop dipersilahkan untuk menanyakan beberapa pertanyaan kepada Tim Pengabdian. Kegiatan dialog terjadi dengan santai namun tetap serius. Ketika dialog dirasa sudah cukup kegiatan selanjutnya adalah praktek penyusunan RPP.

Kegiatan praktek penyusunan RPP menggunakan metode praktik dan diskusi. Dari semua peserta yang ada dibagi ke dalam empat kelompok. Kemudian masing-masing kelompok menganalisis terhadap RPP yang telah dipersiapkan terlebih dahulu. Setelah masing-masing kelompok menyelesaikan analisisnya, mereka dipersilahkan untuk mempresentasikan hasilnya ke depan kelas. Kemudian kelompok yang lain memberikan tanggapan.

Proses selanjutnya setelah menganalisis RPP, masing-masing kelompok langsung mempraktekkan penyusunan RPP. Pemilihan materi disesuaikan dengan basic kemampuan kebanyakan dari anggota kelompok. Selama proses penyusunan, Tim pengabdian selalu mendampingi. Jika ada hal-hal yang perlu ditanyakan siap untuk membantu peserta workshop. Hasil dari pendampingan penyusunan perangkat pembelajaran ini adalah mitra bisa mengaplikasikan penyusunan RPP kurikulum 2013 dengan baik.

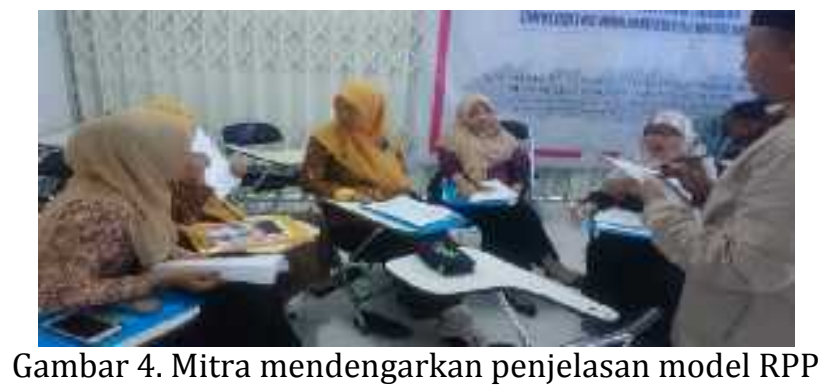

\section{Micro Teaching dan Real Teaching}

Micro teaching dilaksanakan setelah semua materi pendampingan telah usai. Micro teaching adalah salah satu pendekatan atau cara untuk melatih penampilan mengajar yang dilakukan secara micro atau disederhanakan, baik dari segi waktu, materi, jumlah peserta didik, penggunaan metode, media pembelajaran dan unsurunsur pembelajaran lainnya. Tujuan dari kegiatan ini adalah: (1) mempraktekkan metodologi pembelajaran yang relevan secara micro dengan pendekatan islam rahmatan lil'alamin, (2) mendiskusikan hasil pengamatan dan penilaian terhadap praktik micro teaching.

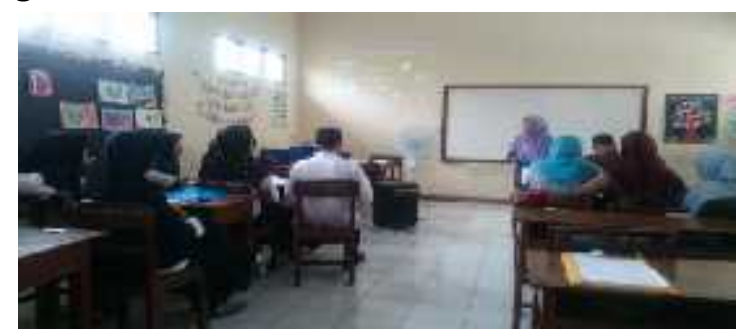

Gambar 5. Mitra sedang melaksanakan Micro Teaching 
Hal yang pertama dilakukan adalah Tim memberikan acuan kepada mitra bahwasanya peserta yang maju adalah perwakilan dari kelompok. Kelompok terbagi menjadi empat. Kemudian masing-masing kelompok menunjuk pewakilannnya untuk melaksanakan real teaching. Selanjutnya dibagikan nomor undian kepada peserta pendampingan. Peserta yang mendapat nomor urut satu maka dia maju yang pertama kali, dan seterusnya berlaku pada nomor-nomor berikutnya. Kemudian ketika satu orang perwakilan kelompok maju untuk micro teaching, maka kelompok lainnya mengamati dan memberikan penilaian. Setelah selesai langsung dibahas bersama peserta lainnya dengan memberikan masukan dan tanggapan.

Kegiatan real teaching merupakan kegiatan pembelajaran langsung yang terukur dan dilaksanakan di kelas yang sebenarnya. Hal ini sebagai implementasi dari hasil workshop. Pengamatan dilakukan oleh Tim pengabdi untuk memberikan gambaran efektivitas dari metode dan internalisasi nilai-nilai Islam rahmatan lil'alamin yang dilatihkan kepada mitra guru. Dari pengamatan ini dapat disimpulkan dampak positif pengembangan kompetensi guru dari sisi profesionalitasya dalam pembelajaran di kelas.

PKM bagi guru tentang metode pembelajaran aktif berkarakter Islam rahmatan lil'alamin telah memberikan wawasan sekaligus kemampuan untuk mengenal dan mempraktekkan pembelajaran yang menarik dan menyenangkan bagi guru-guru mitra di SD Muhammadiyah Pujotomo dan MI Muhammadiyah Donorejo Mertoyudan Kabupaten Magelang.

Salah satu kunci hasil belajar adalah perubahan pemikiran dan perilaku dari kebiasaan guru mengajar (pengajaran) ke kebiasaan peserta didik belajar (pembelajaran) di kelas, melalui kemampuan guru dalam mengelola kelas dan mengembangkan metode pembelajaran aktif (Mawardi, 2018).

Kemampuan Guru dalam mendesain pembelajaran menunjukkan salah satu tingkat profesionalitasnya; karena itu profesi guru adalah pendidik profesional yang mempunyai tugas, fungsi, dan peran penting dalam mencerdaskan kehidupan bangsa. Oleh sebab itu, usaha-usaha untuk meningkatkan kemampuan guru harus terus dilakukan, khususnya mengantisipasi cepatnya laju perkembangan globalisasi.

Pengembangan kompetensi guru terutama berhubungan dengan metode dalam menstransformasikan ilmu pengetahuan dan nilai-nilai, menjadi modal utama untuk meningkatkan mutu pembelajaran. Berkaitan dengan metode yang diterapkan guru, guru harus melibatkan peserta didik untuk berperan aktif dalam pembelajaran, juga memperhatikan gaya belajar yang dimiliki peserta didik, dan mampu membentuk social side of active learning (Munthe, 2009). Pengembangan semacam itu menjadi sangat strategis mengingat tuntutan dalam Peraturan Pemerintah (PP) Nomor 74 Tahun 2008 Tentang Guru, yang menjelaskan bahwa "Guru wajib memiliki kualifikasi akademik, kompetensi, sertifikat pendidik, sehat jasmani dan rohani, serta memiliki kemampuan untuk mewujudkan tujuan pendidikan nasional. Kompetensi Guru meliputi kompetensi pedagogik, kompetensi kepribadian, kompetensi sosial, dan kompetensi profesional yang diperoleh melalui pendidikan profesi". Dalam kompetensi kepribadian, salah satunya menyangkut tentang "mengembangkan diri secara mandiri dan berkelanjutan". 
Seorang guru yang memenuhi standar mutu guru diharapkan mampu mewujudkan pembelajaran yang efektif dan juga menjadi pembelajar sepanjang karir dalam rangka mewujudkan pendidikan yang berkualitas.

Berdasarkan hasil workshop/pelatihan dan pendampingan ini, lebih dari $90 \%$ peserta memahami tentang internaslisasi nilai-nilai Islam rahmatan lil'alamin sebagai pendekatan dari metode pembelajaran yang dilakukan guru. Apabila ditinjau dari kapasitas atau kemampuan dari para peserta dalam mendesain dan penggunaan metode pembelajaran baik dalam menentukan jenis metode pembelajaran aktif yang tepat, pemilihan media baik yang konfensional maupun media berbasis power ponit, perencanan pembelajaran sampai pelaksanaan simulasi pembelajaran, sebagian besar atau $80 \%$ dari jumlah peserta mampu meningkatkan kemampuannya. Gambaran lengkapnya sebagaimana tabel 3.

Tabel 3. Keberhasilan Kegiatan Workshop

\begin{tabular}{|c|c|c|c|}
\hline No & Sebelum workshop & Selama workshop & Setelah workshop \\
\hline 1 & $\begin{array}{l}\text { Peserta belum } \\
\text { memahami metode } \\
\text { pembelajaran aktif } \\
\text { berkarakter Islam } \\
\text { rahmatan lil'alamin }\end{array}$ & $\begin{array}{l}\text { Peserta diberi pengetahuan } \\
\text { dan pemahaman tentang } \\
\text { metode pembelajaran aktif } \\
\text { berkarakter Islam rahmatan } \\
\text { lil'alamin }\end{array}$ & $\begin{array}{l}\text { 90\% peserta memiliki } \\
\text { pengetahuan dan } \\
\text { pemahaman tentang } \\
\text { metode pembelajaran } \\
\text { aktif berkarakter Islam } \\
\text { rahmatan lil'alamin }\end{array}$ \\
\hline 2 & $\begin{array}{l}\text { Peserta belum bisa } \\
\text { mengembangkan media } \\
\text { powerpoint dalam } \\
\text { pembelajaan }\end{array}$ & $\begin{array}{l}\text { Peserta diberi pengetahuan } \\
\text { dan pemahaman secara } \\
\text { praktik langsung tentang } \\
\text { menyusun media yang baik } \\
\text { dan pengembangan fitur-fitur } \\
\text { yang menarik dari powerpoint }\end{array}$ & $\begin{array}{l}\text { 80\% peserta memiliki } \\
\text { pengetahuan dan } \\
\text { pemahaman tentang } \\
\text { mengembangkan media } \\
\text { powerpoint dalam } \\
\text { pembelajaan }\end{array}$ \\
\hline 3 & $\begin{array}{l}\text { Peserta belum } \\
\text { memahami tentang } \\
\text { merancang rancangan } \\
\text { pembelajaran }\end{array}$ & $\begin{array}{l}\text { Peserta diberi pengetahuan } \\
\text { dan pemahaman serta praktik } \\
\text { menyusun RPP berdasarkan } \\
\text { Kurikulum } 2013 \text { revisi } 2017\end{array}$ & $\begin{array}{l}80 \% \text { peserta memiliki } \\
\text { pengetahuan, } \\
\text { pemahaman dan } \\
\text { praktik tentang } \\
\text { menyususn RPP }\end{array}$ \\
\hline 4 & $\begin{array}{l}\text { Peserta belum dapat } \\
\text { mempraktekkan } \\
\text { metode aktif learning } \\
\text { bekarakter Islam } \\
\text { rahmatan lil'alamin }\end{array}$ & $\begin{array}{l}\text { Peserta dibimbing dan } \\
\text { dievaluasi dengan melakukan } \\
\text { micro teaching dan real } \\
\text { teahing }\end{array}$ & $\begin{array}{l}90 \% \text { peaserta dapat } \\
\text { mempraktekkan } \\
\text { pembelajaran dengan } \\
\text { metode aktive leaning } \\
\text { berkarakter Islam } \\
\text { rahmatan lil'alamin. }\end{array}$ \\
\hline
\end{tabular}

\section{SIMPULAN DAN SARAN}

Berdasarkan hasil PKM yang diperoleh selama workshop dan tindak lanjutnya dalam pembelajaran di kelas bagi guru-guru di SD Muhammadiyah Pujotomo dan MI Muhammadiyah Donorejo Mertoyudan Kabupaten Magelang disimpulkan sebagai berikut: (1) Kegiatan PKM ini berupa workshop/pelatihan dan pendampingan yang dikikuti oleh guru dari dua sekolah mitra yaitu SD Muhammadiyah Pujotomo dan MI Muhammadiyah Donorejo, Mertoyudan Kabupaten Magelang; (2) PKM ini didanai dari anggaran DRPM Ristekdikti tahun anggaran 2018, yang didukung penuh LP3M Universitas Muhammadiyah Magelang; (3) Keberhasilan PKM ini tercermin pada guru 
antara lain: (a) memiliki pengetahuan dan pemahaman tentang metode pembelajaran aktif berkarakter Islam rahmatan lil'alamin; (b) memiliki pengetahuan dan pemahaman tentang mengembangkan media powerpoint dalam pembelajaan; (c) memiliki pengetahuan, pemahaman dan praktik tentang menyususn RPP; (d) mempraktekkan pembelajaran dengan metode aktive leaning berkarakter Islam rahmatan lil'alamin.

Adapun saran untuk PKM selanjutnya adalah: (1) Guru yang telah mengikuti kegiatan workshop/pelatihan dan pemdampingan ini diharapkan dapat mengimplementasikan metode pembelajaran aktif berkarakter Islam rahmatan lil'alamin untuk meningkatkan kualitas pembelajaran; (2) Diperlukan dukungan dan kebijakan nyata dari Universitas Muhammadiyah Magelang dan Majlis Dikdasmen PCM Mertoyudan untuk menyelemggarakan kegiatan-kegiatan sejenis dalam rangka meningkatkan SDM guru yang berkualitas.

\section{UCAPAN TERIMAKASIH}

Tim PKM mengucapkan terimakasih kepada (1) DRPM Ristekdikti atas bantuan dana dalam PKM ini; (2) Unversitas Muhammadiyah Magelang atas berbagai fasilitas yang diberikan dalam mendukung PKM ini; (3) Pimpinan Cabang Muhammadiyah Mertoyudan yang memberikan izin dalam melakukan PKM pada lembaga yang dibinanya; (4) Kepala SD Muhammadiyah Pujotomo dan MI Muhammadiyah Donorojo, serta segenap guru yang telah bersedia menjadi mitra dalam program PKM ini. Semoga menjadi ladang amal dalam pengembangan mutu SDM dan pendidikan di Indonesia.

\section{DAFTAR RUJUKAN}

Badan Penelitian dan Pengembangan Kementerian Pendidikan dan Kebudayaan RI. (2017). Dinamika Kebijakan Kurikulum 2013.

Direktorat Jenderal Pendidikan Islam. (2015). Modul Pelatihan Bimbingan Teknis Metode Pembelajaran Pendidikan Agama Islam Rahmatan Lil'Alamin. Jakarta: Direktorat Pendidikan Agama Islam.

Mawardi, I. (2018). Model Pembelajaran Life Skills: Dimensi Penguatan Kurikulum Pendidikan Agama Islam. Magelang: UNIMMA PRESS.

Munthe, B. (2009). Desain Pembelajaran. Yogyakarta: Pustaka Insan Madani dan CTSD UIN Sunan Kalijaga Yogyakarta.

Undang-Undang Guru dan Dosen Nomor 14 Tahun 2005. 
100 J-Abdipamas, Vol. 2, No. 2, Oktober, 2018 